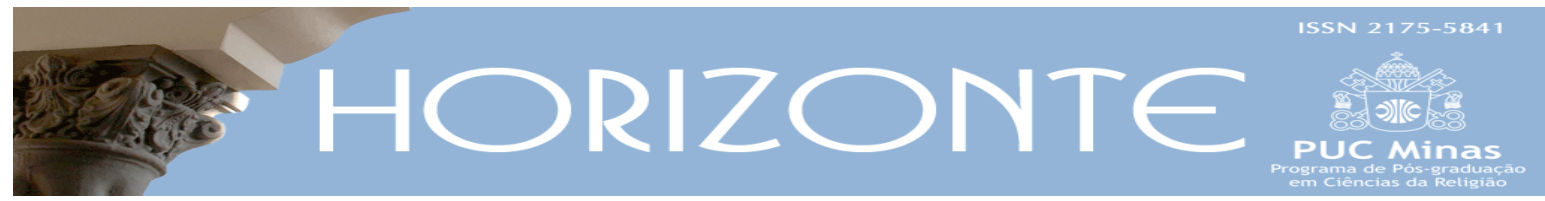

Temática Livre - Artigo original

DOI - 10.5752/P.2175-5841.2015v13n38p941

\title{
Tu Eterno e religiosidade no pensamento de Martin Buber
}

\author{
Eternal Thou and religiosity in Buber's thought
}

Newton Aquiles von Zuben*

\begin{abstract}
Resumo
O ponto axial da reflexão de Buber é a noção de encontro EU-TU. As linhas de todas as relações, se prolongadas, entrecruzam-se no Tu eterno. Com essa afirmação, Buber introduz suas densas considerações sobre Deus, o Tu eterno, o único Tu que por sua própria essência não pode se tornar um Isso. O encontro dialógico EU-TU eterno é uma relação imediata de presença (Gegenwartsbeziehung). Tal é o cenário no qual se pode entender a religiosidade, para Buber, como encontro na presença (Gegenwart), entre o homem e o Tu eterno. E essa relação é uma experiência religiosa que se concebe e se anuncia a partir da experiência humana. As relações dialógicas entre os homens são sinais de uma relação mais perfeita, que é a relação com Deus. O objetivo é mostrar o significado do Tu eterno e da religiosidade como encontro na presença com o Tu eterno na obra EU e TU.
\end{abstract}

Palavras-chave: Martin Buber; Tu eterno; presença; religiosidade.

\begin{abstract}
The axial point on Buber's philosophy is the notion of the I-Thou encounter. All lines of all relations, if extended will meet in the eternal Thou. By affirming that, Buber introduces his dense considerations about God, the eternal Thou, the only Thou who due to his own essence cannot become an It. The dialogical encounter I - eternal Thou is an immediate relation of presence (Gegenwartsbeziehung). That is the background in which one can understand what religiosity means to Buber. It is an encounter in the presence (Gegenwart) between the man and the eternal Thou. And such relation is a religious experience that is conceived and announced in the human experience. Dialogical relations among men are signs of a more perfect relation that is the relation with God. The objective of this article is to show how the meaning of the eternal Thou and of the religiosity as encounter in the presence with the eternal Thou in the work I and Thou.
\end{abstract}

Keywords: Martin Buber; eternal Thou; presence; religiosity.

Artigo recebido em 29 out. 2014 e aprovado em 22 de junho de 2015

* Doutorado em Filosofia. Professor titular do Programa de Mestrado da Pontifícia Universidade Católica de Campinas. País de origem: Brasil. E-mail: nzuben@puc-campinas.edu.br

Horizonte, Belo Horizonte, v. 13, n. 38, p. 941-968, abr./jun 2015 - ISSN 2175-5841 


\section{Introdução}

Martin Buber é considerado um dos eminentes pensadores do fenômeno religioso, no século XX. Suas obras do primeiro período, entre 1903 e 1913, sobre o misticismo cristão medieval, em especial Mestre Eckart e Jacob Böhme, e sobre o misticismo judaico, em especial o hassidismo, seus inumeráveis estudos de hermenêutica bíblica, sobre o judaísmo e sua tradução para o alemão da Bíblia judaica revelam seu particular interesse em aprofundar os estudos sobre a religião, sobre o fenômeno religioso, de uma renovação espiritual do judaísmo. Foi ele quem apresentou ao ocidente o patrimônio dos contos hassídicos e, dessa mística popular, erige uma verdadeira doutrina, uma filosofia existencial que professa a redenção como uma tarefa humana, no sentido em que o homem participa do devir divino.

Reconhecendo sempre sua pertença ao espiritualismo judeu, mantendo-se sempre fiel ao sionismo, ele construiu seu próprio caminho. "Pode-se notar" aponta o filósofo judeu Hayoun,“[...] na sua germanização da Bíblia hebraica que ele praticamente jamais apela às exegeses tradicionais nem a especulações buscadas nas obras de filósofos judeus da Idade Média” (HAYOUN, 2013, p.538). A primeira etapa de seu percurso caracteriza-se por um período de pesquisas sobre o misticismo. De 1903 até por volta de 1913, publicou diversos trabalhos relativos à mística medieval cristã, sobre a mística judaica e especialmente sobre o hassidismo. Sua obra Daniel. Die Gespräche von der Verwirklichung (Daniel. Diálogos sobre a realização), de 1913, representa o ponto de passagem do período místico para um novo modo de pensar, segundo as próprias palavras de Buber. Esse novo período é marcado por uma de suas mais importantes obras filosóficas, cuja atmosfera ainda estava animada por experiências místicas, Ich und $D u$ (Eu e Tu). Publicada em 1923, significou o novo modo de abordar a religião. É considerada uma das obras influentes no campo da filosofia e da teologia. Esse pequeno livro recebeu esse título para publicação. $\mathrm{Na}$ realidade, Eu e Tu seria o 
primeiro volume do projeto de 5 volumes planejado por Buber, cujo título deveria ser Prolegómenos para uma Filosofia da Religião, título inspirado em Prolegómenos para uma Metafísica do futuro, de Kant. Em um fac-símile desse plano se verifica que Eu e Tu se comporia de três partes: 1. Palavra (Wort), 2. História (Geschichte), 3. Deus (Gott). (cf. HORWITZ, 1978, p.269).

Ich und $\mathrm{Du}$ (Eu e Tu) é obra de um pensador visionário que mobiliza seus conhecimentos em filosofia, em mística, em hassidismo, em hermenêutica. Os elevados princípios que jazem no fundamento dessa filosofia, um tanto quanto utópica, configuraram um êxito inesperado e imprevisível. É sua mais importante obra filosófica. Publicada em 1923, representou o novo modo de abordar a religião. É considerada uma das suas mais obras influentes no campo da filosofia e da teologia.

Buber vinha trabalhando em diversos temas dessa obra, desde 1918. Na verdade, esses temas foram expostos numa série de oito conferências, proferidas entre 15 de janeiro e 12 de março de 1922, em Frankfurt, no Freies Jüdische Lehrhaus, com o título Religion als Gegwewart (Religião como Presença). Buber tinha a intenção de apresentar uma fenomenologia da religião. Após essas conferências, com incentivo de seu amigo Franz Rosenzweig, o qual publicara, em 1921, a obra Stern der Erlösung (Estrela da Redenção), Buber encaminha para o editor Ich und $\mathrm{Du}$. De fato, ao comparar-se com o texto das conferências, verificase que essas constituem uma edição prévia oral do livro. As próprias notas do estenógrafo serviram como base a partir da qual Buber escreveu Eu e Tu. A religião é entendida como presença, o "estar-diante-de" (Gergenüberstehen) no encontro com o Tu eterno.

Proponho, neste trabalho, explicitar como Buber concebe o encontro (Begegnung) do homem com o TU Eterno, e o significado daquilo que denomina "situação religiosa" do homem. 
A intuição axial dessa pequena obra Ich und Du é a relação - Beziehung -, na qual se desenrola o encontro do homem com o mundo, a natureza, com outros homens e com Deus. Logo nas páginas iniciais, ele afirma: No principio é a relação. A ontologia da relação é o fundamento para a atualização do encontro. O encontro com o Tu eterno, o Absoluto, relação perfeita, segundo Buber, revela para ele um tipo peculiar de reciprocidade, de outra dimensão daquela que ocorre entre humanos. Essa reciprocidade se dá entre a revelação (Offenbarung) e a fé (Glaube). À luz dessa situação de encontro, revela-se também, conforme observa, a vivência da religiosidade.

Buber, após um período de estudos e reflexões místicas, em especial sobre o hassidismo, volta-se, de modo mais decisivo, para a questão de Deus, o Tu absoluto como o TU eterno. Na obra EU e TU, Deus não aparece antes da terceira parte. As reflexões, lavradas numa linguagem e estilo peculiares, carregada de neologismos linguísticos e expressões de difícil compreensão, podem deixar o leitor com dificuldade para entender o que exatamente o pensador quis dizer. A importância que Buber atribui à linguagem não está isenta de certa dimensão judaica (na tradição da Kabala, Deus cria o mundo pela palavra), no entanto, o relevante aqui é que, filosoficamente, a linguagem reveste uma dimensão constitutiva do ser para a existência humana. O homem fala porque é homem e, ao proferir a "palavra-princípio", ele se faz homem. A linguagem é a condição da relação.

Aqueles que preferem o Deus de Abraão, de Jacó e Jó ao Deus dos filósofos e teólogos devem perguntar-se: "E Deus"? Não indagam como realmente ele é, quais seus atributos, se ele é onisciente ou se a sua existência pode ser provada. Não há interesse em saber o que é Deus. Buber tenta mostrar o eterno Tu a quem os homens podem falar e que sentem que Ele lhes fala, numa relação imediata. O livro está imerso no judaísmo. Não se encontrará ali um sistema, antes uma exortação para que os homens busquem uma vida dialógica. O centro de sua reflexão é a relação do homem com a natureza, dos homens entre si e do homem 
com Deus. A obra de Buber é vasta e multifacetada. Ele próprio declarou-se “atípico". Seria ele um teólogo judeu, como muitos teólogos cristãos e judeus defendem? Seria um filósofo existencialista com convicções religiosas? Recusando essas etiquetas, ele desejou ser um pensador criativo que despertava as almas dormentes, em especial os judeus, por meio da dimensão espiritual do sionismo, a fim de que aspirassem a uma realidade mais profunda. Sua vasta obra sobre o judaísmo e estudos hermenêuticos da Bíblia judaica e sobre o hassidismo o demonstraram cabalmente. Ele poderia antes ser considerado um cientista da religião (Religionswissenschaftler).

Para a compreensão de seu pensamento sobre o Tu eterno, é pertinente observar dois pontos: o hassidismo, como importante elemento na gênese de seu pensamento e vida; e os principais conceitos de sua ontologia da relação, expostos na primeira parte de $E U$ e $T U$, na qual ele apresenta uma fenomenologia da relação fundada nas "palavras-princípio” (Grundwort) como atitudes fundamentais do homem.

Buber tomou contato com o hassidismo em sua infância, quando passou longo tempo com seus avós paternos, cuja residência se situava em Sadagora, na Ucrânia, onde Buber pôde vivenciar a atmosfera entusiástica e religiosa da mística do hassidismo. Nessa localidade, ele pôde interiorizar a espiritualidade e a religiosidade próprias da comunidade hassídica. A marca indelével da mística hassídica sobre a vida e pensamento foi decisiva. Relatando mais tarde esse encontro, Buber reconhece que representava, para ele, não um encontro como pensamento, mas como imagem e sentimento. Para Buber, em uma época que não foi tão fecunda, no plano religioso, o obscuro judaísmo da Polônia e da Ucrânia gerou um fenômeno mais importante da história do espírito, a saber, uma comunidade que vive sua fé, o hassidismo. O hassidismo representa uma forma popular da Kabala, a qual enfatiza a espontaneidade e o fervor do sentimento religioso e as reocupações de ordem ética. Essa mística procura suscitar uma 
renovação na vida religiosa judaica, despertando o entusiasmo do fiel (hassid), encorajando-o a uma constante renovação interior. O hassidismo exerceu forte influência sobre Buber; presidindo, em grande medida, a elaboração de sua concepção de Deus, do homem, do mundo e da religiosidade na existência humana.

Para esse pensador, a originalidade dessa mística no seio do judaísmo só é compreendida se se levar em conta que essa corrente mística visa a renovar o conceito de ação. A ação, o ato (Tat), melhor que qualquer outra manifestação, revela a imagem de Deus que cada homem leva consigo. Adiante, veremos como Buber, ao sistematizar sua abordagem do ato, da ação, estabelece o significado da religião e da religiosidade. A lição do hassidismo para Buber resume-se numa frase: ver Deus em cada coisa, atingir Deus por meio de todo ato autêntico (reine Tat). A salvação do homem não se conquista ao se distanciar do mundo, mas em santificá-lo.

O Tu eterno aparece na $3^{\mathrm{a}}$ parte da obra. Nas duas primeiras partes, temos o cenário conceitual da ontologia da relação, a vida da relação dialógica. A intuição primeira é a relação. "No início é a relação, uma categoria do ser, disposição de acolhimento.” A relação é uma convergência entre dois participantes numa atitude conjunta. "O mundo é duplo para o homem, segundo a dualidade de sua atitude. A atitude do homem é dupla de acordo com a dualidade das palavras-princípio (Grundwort) que ele pode proferir" (BUBER, 2006, p.51). "O essencial (Wesenheiten) é vivido na presença (Gegenwart), as objetividades no passado" (BUBER, 2006, p.58). São duas atitudes, duas palavras-princípio, os pares de vocábulos Eu-Tu e Eu-Isso; são dois mundos. O mundo do TU, do diálogo entredois (zwischen). Não há Eu isolado; o Eu realiza-se no encontro com o TU. Eu-Isso é a atitude de objetivação do outro, de utilização e de experimentação. O mundo do Isso é coerente no espaço e no tempo. A atitude Eu-Tu estabelece o encontro dialógico. Eu-Tu é fugaz, é um encontro imediato (sem intermediários), recíproco. 
Cada ISSO pode tornar-se um TU, e cada TU pode voltar a ser um simples objeto de utilização por parte de um EU. Dizer Tu é não ter nenhuma coisa por objeto. O Eu-Isso é, o mais das vezes, fruto de um ato deliberado; o Eu-Tu se instaura, segundo Buber, por um propósito deliberado e, ao mesmo tempo, por graça (aus Wille und Gnade in einem).

A existência humana, na perspectiva de Buber, se desenrola num continuum de "encontros Tu" (Begegnungen) e de "relações Isso" (Beziehungen). A vida se realiza num movimento de alternância do encontro dialógico: Eu-Tu efêmero, de um lado, e, de outro, a experiência Eu-Isso, sedutora, invasora, coerente no espaço e no tempo. O homem toma conhecimento do mundo, do outro, dos seres em geral como um Isso. A atitude Eu-Tu marca o existir autêntico do homem, pois a palavra-princípio Eu-Tu só é pronunciada pelo homem com todo o seu ser. "O mundo do Isso é coerente no espaço e no tempo. O mundo do Tu não tem coerência nem no espaço e nem no tempo. Cada Tu, após o término do evento da relação deve necessariamente se transformar em Isso" (BUBER, 2006, p.71). A relação é "presença", uma relação imediata, não uma relação espaciotemporal, mas, como observa o filósofo Misrahi, "[...] uma realidade imediatamente percebida para além das determinações empíricas” (MISRAHI, 1968, p.63).

\section{Tu Eterno}

A intenção de Buber era propor uma nova leitura do judaísmo. Para isso, um dos caminhos era entender as relações entre o homem e Deus. Misrahi enfatiza que Deus é o nome dado à experiência da relação absoluta (MISRAHI, 1968, p.29). Buber designa essa relação absoluta como a relação ao Tu eterno.

A terceira parte de $E U$ e $T U$ começa por uma afirmação significativa, que permite compreender a intenção de Buber: construir uma ontologia da relação para entender uma antropologia do encontro que leva a e, ao mesmo tempo, é 
sustentada por uma teofania. "As linhas de todas as relações, se prolongadas, entrecruzam-se no Tu eterno. Cada Tu individualizado é uma perspectiva para ele. Por meio de cada $\mathrm{Tu}$ individualizado a palavra-princípio invoca o $\mathrm{Tu}$ eterno" (BUBER, 2006, p. 99).

Graças a uma compreensão peculiar da linguagem, de acordo com Buber, o homem tem "experiência" (Erlebniss) do mundo. A dupla atitude do homem se constitui pela palavra. Ao dizer, ao pronunciar a palavra-princípio Eu-Tu, o homem institui sua identidade na reciprocidade do encontro. Buber salienta que há o mundo do Tu (Duwelt) e o mundo do Isso (Eswelt). A existência humana, para ele, se desenrola, alternadamente, num continuum de "encontros Tu" e de "relações Isso". "Todavia, a grande melancolia de nosso destino é que cada Tu no nosso mundo deve tornar-se irremediavelmente um Isso" (BUBER, 2006, p.61). E prossegue: "Cada Tu, neste mundo, é condenado, pela sua própria essência, a tornar-se uma coisa, ou então, a sempre retornar à coisidade” (BUBER, 2006, p.61).

Buber considera a experiência originária e fundante que organiza a existência humana no mundo como um face-a-face (Gegenüber), como encontro. A ideia de face-a-face faz lembrar a figura de Moisés, o único dos israelenses a entrar em contato com Deus, para que lhe fosse comunicada sua vocação de libertador do povo hebreu. No Êxodo, pode-se ler: "O Eterno falava com Moisés face-a-face, como um homem que fala a seu amigo" (ÊXODO, 33.11).

É um encontro imediato (sem mediação) e exclusivo entre o Tu absoluto e eterno e o homem. Esse é o fundamento ontológico da teologia de Buber. Teologia, não como palavra sobre Deus, mas uma palavra com Deus. É esse o cenário que encontramos, na terceira parte de $E U$ e $T U$.

Como Buber nos apresenta essa relação especial- Eu- Tu eterno? O que ocorre nesse evento originário do ser religioso do homem? 
Todas as relações com os homens com os seres da natureza ou com as formas espirituais não realizam o existir humano em toda plenitude e em todas as dimensões de seu ser. O Tu inato se realiza em cada ser, mas não se completa plenamente em nenhum.

As linhas de todas as relações, se prolongadas, entrecruzam-se no Tu eterno. Cada Tu individualizado é uma perspectiva para ele. Por meio de cada Tu individualizado a palavra-princípio (Grundwort) invoca o $\mathrm{Tu}$ eterno. Da mediação do Tu de todos os seres, surge não só a realização das relações para com eles mas também a não realização. $\mathrm{O}$ Tu inato realiza-se em cada uma delas, sem, no entanto, consumar-se em nenhuma. Ele só se consuma plenamente na relação imediata para com o Tu que, pela sua própria essência, não pode tornar-se Isso. (BUBER, 2006, p.99).

Com essa afirmação, Buber introduz suas densas considerações sobre Deus. “Os homens têm invocado o seu Tu eterno sob vários nomes” (BUBER, 2006, p. 99). Em cada Tu individual, a palavra-princípio invoca o Tu eterno. Essa função mediadora do $\mathrm{Tu}$ de todos os seres possibilita que a relação possa se realizar. Os nomes de Deus, porém, entraram no reino da linguagem do Isso. Todos esses nomes permanecem sagrados, pois não somente falamos de Deus, mas falamos com Ele. Conforme Buber, aquele que pronuncia o nome de Deus invoca o verdadeiro Tu sagrado de sua vida, o Tu que nenhum outro limita.

Além da esfera inter-humana e da esfera das relações com a natureza, há outra esfera de relação, mais profunda, a relação com o Tu eterno, o único Tu que, por sua própria essência, não pode se tornar um Isso (BUBER, 2006, p. 99). Embora esse Tu tenha recebido diversos nomes, ele sempre pode ser encontrado; pouco importa o nome que lhe demos, ele sempre pode ser encontrado. Quando os homens endereçam louvores a seu Tu, é sempre o mesmo Tu que invocam. Mesmo o não crente se volta, contudo, "[...] para o Tu de sua vida, ao Tu que por nada pode ser limitado" (BUBER, 2006, p.100). 
Nosso encontro com o Tu eterno não é resultado de uma busca, pois é vão tentar procurar Deus. É verdade que o eu, o homem, após ter provado a decepção de ver, em suas relações dialógicas, os "Tu" $(D u)$ se transformarem em "Isso" (Es), aspira a algo além deles. Não é uma procura por Deus, porque não há lugar onde não o possamos encontrar. É ilusório, igualmente, abandonar a própria vida, desviar-se do próprio caminho e, com toda a sabedoria da solidão, ou todo o poder de um ser recolhido, procurar a Deus, já que, mesmo assim, não o encontraríamos. Ao contrário, cada um deve seguir seu caminho e crer firmemente que esse seja o caminho. Note-se aqui a forte influência da mística hassídica sobre a concepção de Buber. Cada relação com o Tu individual significa uma via para a relação essencial (Wesen), a relação com o Tu eterno. Afirmar a ilusão de se buscar ou procurar Deus não significa que o homem seja meramente passivo, ou que Deus seja inacessível. O Tu eterno, dirá Buber, poderá ser considerado pela linguagem, podese falar de Deus, mas esse já não será mais Deus, e sim objeto de análise, um Isso, objeto da teologia. Como a linguagem humana pode apreender Deus? O filósofo e especialista no estudo da Bíblia hebraica Maurice Hayoun afirma: "Para Buber, que se baseia num velho adágio talmúdico, que se invoque Deus como um Ele ou como um Isso, trata-se sempre como uma alegoria. O Talmud explicou bem que a Torah fala de Deus usando a linguagem dos homens" (HAYOUN, 2013, p.270). E prossegue, destacando que todos os antropomorfismos e as insuficiências do discurso humano sobre Deus estão presentes em pleno dia. No entanto, não há outra possibilidade: “[...] a Revelação fala de coisas que ultrapassam - de muito longe - os recursos da linguagem humana" (HAYOUN, 2013, p.270).

O evento da relação se dá entre o homem e Deus. O Tu eterno se apresenta a mim, mas sou eu quem entra em relação com Ele. É o homem que vai ao encontro d'Ele. A relação comporta o escolher e o ser escolhido. Da parte de Deus, há a graça; de nossa parte é a vontade. "O que deve nos ocupar, aquilo pelo que nós devemos nos interessar, não a outra parte, mas a nossa; não é a graça (Gnade), mas a vontade (Wille). A graça nos diz respeito na medida em que nós avançamos 
para ela e aguardamos sua presença; ela não é nosso objeto" (BUBER, 2006, p.100).

O “encontro" não é algo acidental, súbito, ele é um ato. Buber assinala que, da parte do homem, deve operar-se um processo totalizante. "A palavra-princípio só pode ser proferida pelo ser na sua totalidade” (BUBER, 2006, p. 57). O homem se torna uma totalidade atuante, só assim ele pode estar pronto para a relação suprema. Em sua exposição, Buber considera que é essa totalidade atuante é o ato pelo qual o homem se coloca disponível para o encontro supremo. A fim de entrar em relação com Deus, o homem deve ter atingido sua totalidade, isto é, ele não intervém no mundo como algo parcial. Não é com sua dimensão psicológica ou cognoscitiva que o Eu entra em relação com um Tu. Há um aspecto a ser notado, nessa afirmação de Buber, que é primordial: a influência do hassidismo, o qual defende que o homem tem parte ativa na redenção do mundo e na realização de Deus, por meio do mundo. Todavia, pode-se falar do que se requer para entrar em relação com o TU? Quando se alude a conselhos ou preceitos, não se está senão no supérfluo, pois tudo isso se refere ao mundo do Isso. O que importa é a aceitação da presença. $\mathrm{O}$ isolamento do homem pode ser perigoso e tornará difícil a aceitação. Não se renuncia ao Eu, como crê o misticismo. "Não se trata da renúncia do $\mathrm{Eu}$, mas do falso instinto de auto-afirmação que impele o homem a fugir do mundo incerto, inconsistente, passageiro, confuso e perigoso da relação, em direção ao ter das coisas” (BUBER, 2006, p. 101). Não é necessário desfazer-se do mundo sensível ou, como afirma Buber, superar a experiência sensível.

A relação com o Tu eterno é exclusiva, como as outras relações Tu. Isso significa que esse $\mathrm{Tu}$ é destacado de tudo e se torna único diante de nós; tudo existe por sua presença, por sua luz, ele é o horizonte de tudo, durante os breves momentos de verdadeira relação. A relação com Deus é também inclusiva, no sentido de que, afirma Buber, 
[a]quele que entra na relação absoluta não tem mais interesse por nada de isolado, nem com coisas ou entes, nem com a terra ou o céu, pois tudo está incluído na relação. Entrar na relação pura não significa prescindir de tudo, mas ver tudo no Tu; não é renunciar ao mundo mas sim proporcionar-lhe fundamentação. (BUBER 2006, p. 101).

Não é necessário desviar o olhar do mundo para encontrar Deus; só aquele que vê o mundo em Deus é que pode se encontrar em presença de Deus. Buber não tem pretensões ascéticas, as quais propõem a fuga do mundo, ao contrário, sustenta a ideia de que Deus, o absoluto, deve ser realizado neste mundo. Como assevera Misrahi, para Buber, não se pode identificar Deus e o mundo, como pretendeu fazê-lo Spinoza. E prossegue:

No entanto, é também importante constatar que o Deus buberiano não é nem uma coisa, e portanto um ser, mas antes um nome, dado a uma certa experiência fenomenológica de radicalização do mundo. Deus, para Buber é o nome dado à relação absoluta, aquela que se dá e se faz no encontro. (MISRAHI, 1968, p.29).

Trata-se de um Deus que se integra no mundo, por meio da santificação das coisas, e que se isolaria, de alguma maneira, diante de nós, para se tornar presença plena que a tudo ilumina. 'Nada sei sobre um 'mundo' e sobre uma 'vida no mundo' que separe alguém de Deus; o que assim se denomina é a vida com o mundo do Isso, que se tornou estranho, que é experimentado e utilizado" (BUBER, 2006, p. 112). Deus envolve o universo, mas não é o universo. Isso significa um convite para uma nova relação com o mundo; o mundo não seria, doravante, um simples objeto do olhar, mas o lugar da redenção.

O Tu eterno não pode ser procurado; pode somente ser encontrado. Ele se torna inacessível, na medida em que o inacessível traduz, de alguma maneira, o revés da apropriação. Se ele é o mysterium tremendum, cuja presença nos causa medo, ele é o todo, o todo presente, o mistério da evidência que me é mais próximo que o meu próprio ser. Entende-se, com isso, que Buber supera a oposição tradicional entre imanência e transcendência. Deus é o "todo outro" é também o "todo mesmo", o todo presente. "Esta síntese de um Deus objetivo e separado de 
nós, de um lado, e de um Deus subjetivo, que faça parte de nós, de outro lado, deve ser superada por uma síntese mais profunda da ênfase, posta por Buber, no encontro perfeito EU-TU” (FISON, 1950, p.23 apud FRIEDMAN, 1955, p. 223).

A relação ao $\mathrm{Tu}$ eterno, o face-a-face, não se reduz a um simples "sentimento de dependência”. Na perspectiva de Buber,

[...] pretende-se ver, como elemento essencial na relação com Deus, um sentimento chamado "sentimento de dependência" ou mais claramente, em termos mais recentes, o sentimento de criatura. Por mais correto que seja fazer realçar e definir esse elemento, acentuando-o de modo exclusivo, se desconhece o caráter da relação perfeita. (BUBER, 2006, p. 103).

De fato, certos sentimentos podem acompanhar a relação ao Tu absoluto, mas essa relação não pode consistir em sentimentos. Como cada relação EU-TU, essa relação é um fato metafísico e metapsíquico entre o Eu e o Tu. O sentimento está sempre submisso ao dinamismo da alma, onde existem outros sentimentos, e a uma tensão interna de polaridade, vale dizer, todo sentimento é condicionado por seu contrário. Assim declara Buber: “A relação absoluta que, na realidade, engloba todas as relativas e não é parcial como estas, mas total com realização e unificação delas, é relativizada do ponto de vista psicológico, na medida em que é reduzida a um sentimento delimitado e destacado”(BUBER, 2006, p. 103).

O face-a-face com Deus não é um fato psicológico, suscetível de ser descrito como um fenômeno, mas é um ato livre de um ser que é um Eu. A relação perfeita ocorre além das oposições de polaridade. Se nos sentimos dependentes na relação pura, mais do que em outra qualquer, sentimo-nos, ao mesmo tempo, livres. É nisso que consiste a "coincidência dos opostos" à qual já se referia Nicolau de Cusa, a propósito de Deus: sentir a mais completa liberdade na maior dependência ou, conforme prefere Buber, sentir-se criador e criatura. 
Do ponto de vista da alma, a relação perfeita só pode ser concebida como bipolar, como uma coincidentia oppositorum", como união dos sentimentos contrários. Sem dúvida, um dos pólos- reprimido pela atitude fundamentalmente religiosa da pessoa - desaparece à consciência retrospectiva e só poderá ser lembrada na profundeza mais pura e imparcial da introspecção. (BUBER, 2006, p.103-104).

Sendo livre o homem, ele se sente cocriador com Deus, capaz de intervir na história e nos destinos do mundo e cooperar na salvação, na reunificação de Deus, a sua Shekina exilada no mundo. "Que necessitas de Deus, mais do que tudo, sempre o sabes em teu coração: porém não sabes também que Deus necessita de ti, de ti na plenitude de sua eternidade?” (BUBER, 2006, p.104). Se temos necessidade de Deus para ser, Ele tem necessidade de nós para realizar o significado de nossa vida. Se Deus não precisasse do homem, nada mais teria sentido, nem o homem ou sua existência, nem o mundo.

\section{A experiência mística}

A realidade primordial da relação com o Tu eterno não é meramente uma experiência mística. Buber apresenta uma clara crítica aos misticismos tradicionais, porque, segundo ele, levam a um sério inconveniente, que é colocar o Eu em questão. O Eu seria engolfado pelo Ser que é seu fundamento. Na opinião de Buber, os misticismos afirmam que o Eu seria como que absorvido no serAbsoluto. Assim, comprometem a dualidade e negam um fator muito importante da relação sagrada Eu-Tu, a saber, a "mutualidade" ativa, bem como negam, por conseguinte, a própria relação. O misticismo buberiano reconhece o lugar do Eu, sujeito, como arcabouço do "ato religioso". Buber está convicto de que o Eu é a "arca celeste" a qual suporta e funda a relação pura.

Buber distingue dois modos de acontecimentos, nos quais se perde consciência da dualidade. Aponta dois tipos de eventos, confundidos pelo 
misticismo. O primeiro é aquele no qual a alma chega à união. Este tem lugar no próprio homem, e não entre Deus e o homem. Todas as forças são concentradas num mesmo núcleo; é um instante decisivo para o homem e, graças a ele, o homem poderá estar apto para a obra do espírito, para o mistério da salvação e, finalmente, para o encontro. O homem pode, também, se comprazer na satisfação que essa concentração lhe proporciona e recair na dispersão.

O segundo fenômeno tem lugar entre Deus e o homem; é um ato de relação que revela a passagem da dualidade à unidade. É o momento do êxtase, no qual o que era sentido como união - união na qual o homem se vê fundir na divindade, se vê divinizado, de alguma maneira - nada mais é que a dinâmica da relação. O visionário, em êxtase, crê encontrar-se em face de uma união na qual se viriam a misturar o eu e o tu. Ao contrário, é uma união vital sentida com tal intensidade que o eu e o tu, entre os quais ela se instaura, são esquecidos. Essa teoria desconhece uma coisa essencial: a realidade da vida. Na realidade vivida, mesmo na realidade "interior", não há unidade de ser, mas tudo deve se mudar em ação. A força aprofundada da realidade é a ação mútua, "[...] o homem inteiro, sem reserva, e o Deus que a tudo abarca, o Eu unificado e o Tu ilimitado" (BUBER, 2006, p.108). A realidade vivida exige o Eu unificado, a unificação, a concentração de todas as forças da alma num mesmo foco. Diferente daquela absorção, absorção que só quer conservar o que é autenticamente puro, renunciando ao resto, essa concentração de forças, num Eu unificado, pretende integrar tudo. "Não quer o ser abstrato, mas o homem inteiro, não diminuído. Quer a realidade, e é a realidade” (BUBER, 2006, p.109).

Aos olhos de Buber, a teoria da absorção repousa sobre uma ilusão: o espírito humano, curvado sobre si mesmo, imagina que está agindo no interior do homem. Ele age a partir do homem, entre o homem e aquilo que não é o homem (BUBER, 2006, p.111). Renunciando a esse significado da relação, o espírito, dobrado sobre si mesmo, reduz Deus e o universo a um simples estado de alma. 
Buber afirma que as palavras de Budha - "Eu anuncio, amigo, que o corpo do asceta, de seis pés de altura, e dotado de sensibilidade, contém o mundo, a origem do mundo, a salvação do mundo, e a vida que leva à salvação do mundo" - são verdadeiras, de alguma maneira, mas, no fundo, não são muito justas, pois a origem e a salvação do mundo estão, nem em mim, nem fora de mim, pelo simples fato de que não "são" (BUBER, 2006, p. 111). Elas são um "devir", são produzidas sem cessar, e acontece da mesma maneira com o meu ser, a minha vida; eu, a origem e a salvação do mundo, somos solidários. Não dependem, contudo, do fato de eu afirmar ou negar o mundo na minha alma (cf. BUBER, 2006). O que importa é como o homem vai dirigir sua atitude de alma, em face do mundo. Ressalta Buber:

\footnotetext{
Nada sei sobre um "mundo" e sobre uma "vida no mundo" que separe alguém de Deus; o que assim se denomina é a vida com o mundo do Isso que se nos tornou estranho, que é experimentado e utilizado. Aquele que verdadeiramente vai ao encontro do mundo, vai ao encontro de Deus. É necessário se recolher e sair de si, realmente os dois. O "um-e-outro" que é a unidade. (BUBER, 2006, p.112).
}

Os misticismos, tanto os Orientais quantos os do Ocidente, os quais afirmam a relação com Deus como uma pura união, tornam essa união como um fim em si e, por conseguinte, toda responsabilidade do Eu é recusada, em proveito do Tu. Tais atitudes místicas são dois fenômenos, dois movimentos inversos, mas que levam ao mesmo resultado, isto é, a negação do Eu. Quer se trate de fusão do Eu em Deus, ou de abolição, por absorção, de um pelo outro, a união mística significa sempre negação de dualidade e, por consequência, do Eu. Ou há abolição do $\mathrm{Eu}$, pois a dualidade cessa de existir, ou é o Tu que não pode subsistir, porque a verdade é a unidade do "si". Na primeira atitude, ou o eu, desembaraçado de sua ipseidade, vai se identificar com Deus, ou Deus vem se unir ao ser do eu. Na segunda atitude, o indivíduo, também desembaraçado da própria ipseidade, existe na verdade como "Si-mesmo". Em breves palavras: o essencial dessas tentativas é a negação de dualidade do $\mathrm{Eu}$ e do Tu, para dar lugar à unidade, ilusória e enganadora, já que se crê ôntica, quando, na verdade, é psicológica e, por isso, 
frágil e passageira. Com efeito, o místico não conhece uniões místicas permanentes, e, logo que ele sai da união mística, do êxtase, ele reencontra sua consciência dispersada, num mundo dividido, consciência que está tão longe de Deus quanto de si mesma. Contra o sentimento do místico, que crê experimentar a unidade, ao fugir da dualidade, Buber sustenta que não há senão uma ilusão, porque, no exato momento em que a alma crê provar "viver" a união com o divino, ela não apanha, realmente, nada mais que a própria unidade. Vimos, acima, Buberafirmar que, na realidade vivida, não há unidade do ser. A doutrina de Buber se opõe às concepções modernas de relações de consciências, cuja origem deve ser procurada na ideia de fusão extática das doutrinas místicas; ele reivindica a verdade e a realidade da relação, que é plenamente realizada por dois seres que se encontram, face-a-face, numa real mutualidade. A ontologia do encontro de Buber não admite, pois, nenhuma negação do $\mathrm{Eu}$, o $\mathrm{Eu}$ da relação dialógica, isto é, aquele que encontra e que pode ser encontrado. Esse Eu deve estar plenamente presente, mesmo quando aquele que se encontra em frente ao homem, no encontro dialogal, é o próprio Absoluto, o Tu eterno.

O "face-a-face" ou a relação com o Tu eterno, não pode ser realizado senão pela plena luz presente de um Eu que se encontra totalmente "diante" do Outro. Buber faz referência a uma doutrina da dependência:

A doutrina da dependência não deixa ao Eu, que sustenta o arco universal da relação pura, senão uma realidade, tão vã e débil a ponto de não acreditar mais que ela seja capaz de sustentar algo; enquanto eu uma doutrina da absorção deixa desaparecer esse arco no momento de sua perfeição, a outra considera-o uma quimera ser superada. (BUBER, 2006, p.105).

A relação Eu-Tu é frágil e suscetível, a cada instante, de tornar-se um Isso, que é mais possante e contínuo. Buber assinala que essa passagem da relação EuTu para o mundo do Isso não significa um relaxamento necessário da relação, mas, antes, de sua atualidade imediata. O existir humano se completa em uma alternância sucessiva de latências e de atualizações do Eu-Tu. Cada Tu, neste 
mundo, é constrangido, por natureza, a se tornar coisa, suscetível de cair para o mundo do Isto. "Só uma relação, aquela que abarca todas as coisas, permanece atual, mesmo quando em estado latente. Um único Tu tem a propriedade de nunca cessar de ser Tu, para nós” (BUBER, 2006, p.115). Essa é a grande melancolia de nosso destino, sublinha Buber, na primeira parte de EU e TU. Conhecemos, sem dúvida, momentos de afastamento de Deus; mas, não conhecemos a ausência de Deus. "Nós é que não estamos sempre lá” (BUBER, 2006, p. 115)ํ․

Se, no mundo, toda relação é alternadamente latente e atual, ou, numa bela imagem empregada por Buber, se o "[...] Tu individual está sempre sujeito a se fechar na crisálida do Isso, para deixar repousar suas asas” (BUBER, 2066, p.115), na relação pura, porém, o momento de latência não é senão uma pausa para permitir à atualização de tomar fôlego. "O Tu eterno é um Tu por sua essência; é nossa natureza que nos obriga a inseri-lo no mundo do Isso e na linguagem do Isso" (BUBER, 2006, p.115). O mundo do Tu encontra sua coerência no ponto de encontro das relações com o Tu eterno. Todos os privilégios do mundo do Isso se esvaem no privilégio da relação perfeita. É esse privilégio que permite, de um lado, o estabelecimento de uma vida de relação no mundo, além dos momentos isolados de relação, e que, de outro lado, faz que o mal não se torne absoluto e radical.

Buber retoma suas reflexões dobre as esferas de relação dialógica. Realmente, é um mundo, uma vida de relação com diversas manifestações possíveis. O mundo da relação, afirma ele, se realiza em três esferas: a esfera da natureza, aquela com os homens, e, a terceira, com as essências espirituais. Na primeira, chegamos ao limiar da linguagem; na segunda, a relação toma forma de linguagem; na terceira, a relação, embora muda, engendra a linguagem. As três esferas são vias que nos levam à presença do Verbo. "Em cada uma dessas esferas, afirma Buber, em cada ato de relação, por meio de tudo o que se nos torna

\footnotetext{
${ }^{1}$ Buber usará posteriormente a ideia de "Eclipse de Deus" em sua obra Gottesfinsternis, publicada em 1952. Essa tradução não revela exatamente a intensidade do termo alemão. Gottesfinsternis quer enfatizar o que é sombrio, obscuro. Falar de eclipse de Deus é afirmar que, às vezes, Deus se envolve por obscuridade.
} 
presente, vislumbramos a orla do Tu eterno...Todas as esferas são incluídas nele, mas ele não está incluído em nenhuma" (BUBER, 2006, p. 117).

Quando da relação perfeita com o Tu eterno, todas essas vias das relações nas três esferas a que alude Buber, na primeira parte da obra, formam um único caminho, a "via real". A esfera por excelência é a vida com os homens, onde se desenrola a linguagem, e onde o Eu e o Tu estão na lealdade e na reciprocidade do diálogo; estão realmente inseridos na dualidade ação-paixão; são contempladores e contemplados, amantes e amados. Esse "grande portal" engloba, em sua moldura, os dois portões laterais. Para Buber, a relação com o homem é o símbolo da relação com Deus, na qual a invocação recebe a verdadeira resposta, "[...] com a reserva de que, na resposta de Deus, Tudo, e o Todo, ele-mesmo, se revela como linguagem" (BUBER, 2006, p. 118). É a Revelação que se descobre, revelação que é essencialmente presença. Buber se pergunta se não há outra porta para o encontro com Deus. Enfatiza ele que a solidão também pode ser uma porta, porque ela desvincula o homem do comércio com as coisas do mundo do Isso, que ele experimenta e usa. Porém, é preciso entender bem o verdadeiro significado da solidão. Se, por solidão, entendermos a ausência de toda relação, ou a torre de marfim para onde o homem se evade para se entreter consigo mesmo, então, essa solidão se torna uma perda que lança o homem no abismo "[...] onde o homem imagina ver Deus mesmo, e conversar com o próprio Deus" (BUBER, 2006, p. 118).

A relação pura apresenta uma estrutura vital que é a "solidão do Eu em presença do Tu". "Esta solidão é verdadeira, isto é, um isolamento em relação ao mundo mas que pode, ao mesmo tempo, incluir o mundo inteiro no Eu" (BUBER, 2006, p.118). Uma solidão na qual o homem entra em diálogo (na realidade, um falso diálogo) consigo mesmo, não pode, de jeito nenhum, conduzir a Deus. Devemos compreender bem que a relação não é um modo natural de estar-com, que poderia, com efeito, nos deixar confundidos e indeterminados na massa 
indiferente no anonimato da multidão. Ela é uma dimensão ativa e exclusiva, criadora, contando com a solidão, que será superada. Aliás, o papel paradoxal da solidão é justamente o de nos permitir a separação em relação à multidão sem rosto, e, ao mesmo tempo, de nos abrir o caminho para o encontro autêntico com o outro. A solidão é causa de angústia existencial, pois, não somente nos deixa sós, mas, mais profundamente ainda, é uma ruptura, uma dilaceração de nosso próprio ser. A solidão é uma carência que nos esconde o Ser. Há um vazio em nosso ser, que não pode ser preenchido por um objeto, um valor ou uma tarefa. Só a realidade do $\mathrm{Tu}$, encontrável no mundo dialogal, é desvelamento e geradora de presença.

Da mesma maneira, o homem não irá ficar face-a-face com Deus simplesmente por desviar-se dos ídolos - a pátria, o dinheiro e outros bens finitos - que se tornaram valores absolutos entre ele e Deus. Certa concepção moderna, nota Buber, crê que bastaria mostrar ao homem a relatividade desses valores, para que o homem se afastasse deles. Essa concepção se baseia na suposição de que a ligação do homem com esses bens finitos, esses ídolos, seria da mesma natureza que a relação que o homem entretém com Deus. Isso não é exato. A ligação do homem com os bens finitos, “com as coisas particulares”, é do reino do Isso; o homem deles se utiliza, e faz deles um objeto de prazer. Ademais, o homem que está dominado, preso pela veneração desses bens, não tem outro caminho para chegar a Deus, senão pelo retorno, “[...] o qual é, não somente uma mudança de objetivo, mas uma mudança de movimento" (BUBER, 2006, p. 119), pois o homem que se converte por uma substituição, "possui um simples fantasma [...] que ele chama Deus”. O conceito de Retorno (Umkher) é um dos termos axiais de $E U$ e $T U$. Essa é a tradução que Buber apresenta do termo hebraico $t^{\prime}$ shuvah, que significa "retorno". O termo é encontrado na Bíblia - Deuteronômio 4:30; Isaías 10:21 e 19:22; Jeremias 4:1 - significando "retorno a Deus". A doutrina judaica afirma que o homem pode a qualquer momento retornar a Deus e ser aceito. Deus pode, a qualquer momento, perdoar aqueles que se arrependem. No livro todo, Buber defende essa relação imediata entre o homem e Deus, dispensando qualquer 
mediação. Nesse ponto e na ênfase com que trata do retorno, Buber está fiel à tradição religiosa judaica. Essa relação imediata está relacionada com o clima de intimidade da qual EU e TU todo está imbuído.

Isso nos leva à consideração de pontos essenciais descobertos na relação, no face-a-face com o Tu eterno. É o que Buber denomina "situação religiosa”.

\section{A situação religiosa do homem}

Ao sair da relação perfeita, o homem é transformado, mais lúcido, mais real, adotando um olhar diferente sobre o mundo. Ele se encontra ancorado no mundo. Buber fala de uma passagem da "religião" à "religiosidade”.

A situação em que a relação Eu-Tu coloca o homem em presença de Deus, Buber a chama de "religiosa". Para sistematizar sua abordagem do "ato", Buber faz a distinção entre religião e religiosidade. No seio do hassidismo, havia duas correntes de crentes: uma facção, os mitnagdim, considerada legalista ao extremo, dava importância excessiva aos sinais exteriores da vida religiosa, à prática dos mandamentos, negligenciando as disposições do coração e ao aperfeiçoamento da vida interior. De outro lado, os hassidim (piedoso), facção que reconhecia maior importância na experiência vivida e na santidade de cada ato, no entusiasmo da vida comunitária. A religiosidade é ligada à sensibilidade do ser humano, a qual se renova sem cessar e é capaz de entusiasmo e admiração. Graças à religiosidade, o homem entra em contato vivo com o Absoluto. A religião, por outro lado, constitui um conjunto de usos, ritos e leis que se impõem. Buber reconhece na religiosidade um fator de criatividade e de busca constante de renovação e aperfeiçoamento. A religiosidade é marcada pelo encontro com o Absoluto. A religião se caracteriza pela submissão à lei. A religião se contenta em manter o eu existente; a religiosidade é voltada para a renovação. O ato renovado revela a ideia de enriquecimento, própria à relação absoluta. Para o hassidismo, o homem pode 
venerar e orar a Deus em qualquer momento e por meio de qualquer ato. De acordo com Buber, não é a natureza do ato que é determinante, mas sim sua santidade, e é a alma do homem e somente ela que determina a qualidade do ato.

Qualquer que seja a ordem do vivido, não conceitual, pode-se tentar tomá-la em consideração, para dela extrair o significado exato. Buber escreve o termo entre aspas, para marcar bem o caráter essencialmente paradoxal, antinômico e insolúvel de tal situação. É justamente o paradoxo que faz a essência das antinomias, próprias a essa situação:

A situação "religiosa" do homem, sua existência na presença é caracterizada por antinomias essenciais e insolúveis. O fato de serem insolúveis constitui a essência destas antinomias. Quem admite a tese e rejeita a antítese, altera o sentido da situação. Tentar pensar uma síntese é destruir o sentido da situação. Esforçar-se em relativizar estas antinomias é abolir o sentido da situação. Querer resolver os conflitos destas antinomias com outra coisa a não ser a vida, é pecar contra o sentido da situação. O sentido da situação é, de um lado, que ela deve ser vivida com todas as suas antinomias, e, de outro, ela só pode ser vivida sem cessar, sempre nova, imprevisível, inimaginável, impossível de ser descrita. (BUBER, 2006, p. 112-113).

Ao lado desta característica, ela possui outra: é a de ser, sem cessar, nova. Que significa o caráter paradoxal dessa situação? Ela implica e é, de alguma maneira, o paradoxo, pois ela engloba a liberdade e a necessidade, a atividade criadora e a dependência. Se eu estou consciente de ser dependente de Deus, de estar em suas mãos e, ao mesmo tempo, se eu sei que minha cooperação é essencial e que tudo depende também de mim, não posso escapar a esse paradoxo; minha situação pertence, simultaneamente, às duas ordens. "Eu devo tomar sobre mim a responsabilidade de as viver simultaneamente e, quando as vivemos, elas são uma só” (BUBER, 2006, p. 113).

Outro aspecto dessa antinomia se encontra no fato de que a relação pura, o encontro face-a-face com o Tu eterno e, portanto, também a espiritualidade de Deus, em virtude da "mutualidade" essencial a toda relação dialogal, não se realizam e se desenvolvem plenamente, senão dentro do mundo. Buber, aqui, 
mantém vínculo com seus primeiros escritos, influenciados pelo hassidismo. "O homem não pode fazer justiça a esta relação com Deus, que lhe foi repartida, senão quando, na medida de suas forças, em cada dia, ele realiza Deus no mundo" (BUBER, 2006, p. 113). Realizar Deus no mundo significa, em outras palavras, afirmar a imanência e a transcendência de Deus. Isso quer dizer igualmente que, se "[...] para fazer justiça a essa relação", o homem é convidado a "realizar Deus no mundo”, Deus não está no mundo, nem nesse mundo. E, levando ainda mais longe: se é possível realizar Deus no mundo, isso significa que Deus não será elemesmo, verdadeiramente "realizado", senão em, e por este mundo. Nesse ponto, Buber ofereceria o flanco aos ataques de teólogos, se não se reportasse explicitamente a uma experiência vivida, a qual não poderia ser descrita conceitualmente, salvo de uma maneira paradoxal. Buber é bastante explícito, quando salienta que toda tentativa de tornar relativas tais antinomias equivale a destruir o significado da situação:

Assim, esforçar-se em relativizar essas antinomias é abolir o sentido da situação. Querer resolver os conflitos dessas antinomias com outra coisa a não ser com a vida, é pecar contra o sentido da situação.O sentido da situação é, de um lado, que ela deve ser vivida com todas as antinomias, e, de outro, que só pode ser vivida sem cessar, sempre nova, imprevisível, inimaginável, impossível de ser descrita. (BUBER, 2006, p. 112-113).

Isso nos leva a outra característica, própria à situação "religiosa” do homem, a saber, que ela se revela, continuamente, como nova. O encontro é, essencialmente, um evento que deve ser constantemente renovado. É um ato, e não um estado; essa ação é a fonte da renovação contínua do Eu, que está em relação. Há, nessa renovação, uma ideia de enriquecimento, peculiar à relação absoluta. Outro aspecto da situação religiosa do homem, entrevisto por Buber, assim poderia ser explicitado: "Diz-se, do homem religioso, que ele não tem necessidade de estar em relação com o mundo e com os seres, porque o estágio da vida social, determinada desde o exterior, seria superado por uma força que só 
agiria de dentro" (BUBER, 2006, p.120). No entanto, Buber rejeita essa afirmação, porque é justamente nas relações com o $\mathrm{Tu}$ individualizado que a palavra fundamental evoca o $\mathrm{Tu}$ eterno. A afirmação se funda sobre a confusão de duas realidades bem diferentes, expressas, por falta de melhor termo, pela palavra "social”. Temos, de um lado, uma comunidade que se baseia na vida de relação e, de outro, uma simples reunião de indivíduos, sem relação essencial entre eles. Ver o homem "religioso" como alguém que não tem necessidade de uma vida de relação com o mundo e com outros homens é fazer, indevidamente, uma divisão entre sua vida de "[...] relação real com Deus, e sua relação irreal de Eu-Isso, com o mundo" (BUBER, 2006, p.121). Por mais profundos que sejam sua interioridade e recolhimento, o religioso continua sempre no mundo. Aquele que não entretém uma ligação dialogal com o mundo o considera necessariamente como objeto, um Isso que ele experimenta e usa. "Não se pode, a bem da verdade, rezar para Deus e usar o mundo. Aquele para o qual o mundo é essencialmente aquilo do qual se tira proveito, enfocará Deus da mesma maneira” (BUBER, 2006, p. 127).

\section{Considerações finais}

Se se abordar a obra $E U$ e $T U$ como um ensaio filosófico que tenta apresentar uma doutrina sistemática, não será difícil criticá-la, encontrando passagens incompreensíveis, aporias, paradoxos. Ao contrário, podemos talvez entender melhor se atentarmos a duas expressões de Buber, muitos anos depois, numa obra consagrada ao pensamento do autor, organizado por Paul Arthur Schilpp e Maurice Friedman - The Philosophy of Martin Buber, publicada em 1967. Na parte intitulada Replies to my critics, afirma Buber: "O que ocorreu para mim foi que todas as experiências que tive durante os anos 1912 a 1919 tornaramse presentes para mim, em grande parte, como uma intensa experiência de fé" (SCHILPP; FRIEDMAN, 1967, p.689). E, mais adiante, ressalta: "Naquela época eu escrevi o que escrevi movido por uma intensa inspiração. E o que tal inspiração oferece não se pode alterar, mesmo se em detrimento da exatidão. Pois, só se pode 
mesurar aquilo que se adquire, não o que se perde" (SCHILPP; FRIEDMAN, 1967, p.706). Nesse texto, Buber se posiciona frente às críticas recebidas e solicitações de esclarecimento constantes nos diferentes estudos apresentados na obra coletiva. $\mathrm{O}$ texto da $1^{\mathrm{a}}$ edição de $E U$ e $T U$ jamais foi alterado por Buber. Somente na edição de1957 ele acrescentou um "Post-scriptum”, pelo qual esclarece diversas dúvidas que lhe foram endereçadas, concernentes a diversas passagens e conceitos da obra. A ontologia do encontro, tal como formulada por Buber, é, sem dúvida, a base sobre a qual se desenvolveram suas ideias a propósito de Deus como Tu Eterno, e de suas intuições sobre a relação entre o humano e o divino como pessoa absoluta.

Para Buber, Ele se apresenta ao eu humano na qualidade de Tu. "Eu estou presente", ouve Moises no monte Sinai (EXODO 3,14). A relação do homem com o $\mathrm{Tu}$ Eterno se inscreve em filigranas, em todas as relações Eu-Tu que o homem mantém em sua existência. O "ser-em-relação" é propriamente o essencial da revelação. Esse é o fenômeno da presença de Deus. A presença, ou o "instante presente", não é o presente pontual, a marca de uma parada no devir do tempo, mas, paradoxalmente, é algo de fluente, algo que está em movimento e, ao mesmo tempo, algo que permanece e que nos aguarda sempre. Tal "instante presente" retorna incessantemente ao mundo do Isso, tornando-se passado. Buber usa aqui uma linguagem antitética, para expressar o inefável instante da relação. É na relação e pelo encontro dialógico que Deus se revela e se dá a conhecer aos homens. À interpelação de Deus, o homem responde pela fé (emuna). A transcendência de Deus se dá a conhecer no coração da experiência humana. Dizer Tu a Deus traduz uma especial percepção da transcendência divina, ao mesmo tempo em que mantém a possibilidade de apreendê-lo e entrar em relação com Ele. A transcendência de Deus para Buber só pode ser vivida no cotidiano da existência, no seio de uma relação dialógica. Compreender Deus como pessoa releva de uma vontade de trazer o ser e a pessoa de Deus ao alcance do humano. Deus como pessoa, Buber o descobre no Antigo Testamento. Esse Deus se volta aos humanos e se oferece como pessoa, para que o homem possa entrar em relação 
com Ele. Na qualidade de Tu, Deus adentra no campo da experiência humana. O ser de Deus não designa algo abstrato, acessível ao intelecto. Deus não se revela como uma abstração sobre o ser, mas como uma experiência concreta (Erlebnis), a qual se traduz por um "ser-concreto-com-os-homens".

“As linhas de todas as relações, se prolongadas, entrecruzam-se no Tu eterno. Cada Tu individualizado é uma perspectiva para ele. Por meio de cada Tu individualizado a palavra-princípio (Grundwort) invoca o Tu eterno" (BUBER, 2006, p. 99). Com esse pensamento, Buber nos dá a entender a experiência que o homem pode fazer de Deus, em sua existência. Entendemos, com essa afirmação, que experiência de Deus não precede, para Buber, as relações que o homem pode ter com a natureza e os outros homens. Ao contrário, essas precedem o domínio da experiência divina. O pensamento teológico de Buber se enuncia a partir da experiência humana. A experiência religiosa se inscreve na experiência cotidiana dos homens.

O momento da relação pura não é uma passagem, é um evento (Geschehen) no qual algo ocorre no ser humano e com o ser humano; ele recebe algo que não tinha antes. Aquilo que ocorre ao ser humano na "relação pura Eu - Tu eterno" não é um conteúdo, mas uma presença como força (eine Gegenwart als Kraft). Com isso, Buber se coloca numa posição de ruptura com o culto da escrita e se afirma como um partidário de uma religiosidade do espírito, a qual tem sua manifestação no dar-se e receber da presença. $\mathrm{O}$ ato da relação pura consiste no instante (Augenblick) que não tem nenhuma continuidade no tempo. No entanto, assinala Buber, o ser humano aspira a dar-lhe duração. Assim, Deus se torna objeto de fé. É a fé que atribui continuidade à relação pura. A fé sustenta a latência da relação pura. $\mathrm{O}$ ato de relação pura consiste na solidão do $\mathrm{Eu}$ com o Tu. Contudo, o ser humano a estende à comunidade (Gemeinschaft). Assim, Deus se torna objeto de culto. A fé dá continuidade no tempo e o culto dá continuidade no espaço. 
A ontologia do encontro e a intuição da dualidade de atitudes proposta por Buber propiciaram o entendimento bem peculiar do Tu eterno. $\mathrm{Na}$ atitude $\mathrm{Eu}$-Isso, Deus é conhecido como objeto, do qual posso falar e buscar sua essência, um deus dos filósofos. A distinção entre as atitudes Eu-Isso e Eu-Tu permite a abordagem de Deus como Tu eterno, não como um objeto de análise, mas como pessoa.

Há, desse modo, a palavra sobre Deus, objeto de conhecimento, e a palavra com Deus no evento do encontro dialógico. O pensamento de Buber sobre o Tu eterno é bem problemático para a crítica contemporânea. Esse pensamento se inscreve num percurso autobiográfico bem dramático. De fato, não se pode reduzir uma teoria à vida de um autor, mas, no caso preciso de Buber, o clima existencial na época em que gestava a obra e inúmeras frases são profundamente marcadas por sua experiência pessoal. Nisso também há algo de paradoxal. Os anos que antecederam a elaboração de $E U$ e $T U$ configuravam um cenário marcante pela religiosidade. Buber era um crente, mas um crente solitário que não fazia parte da comunidade dos crentes. Ele vivia sua crença na solidão, numa religiosidade pessoal íntima, distante de qualquer religião institucional. Não há registros de que tenha em alguma ocasião entrado em uma sinagoga. Apesar disso, são admiráveis suas descrições das orações hassídicas. Transcrevia com nostalgia o mundo religioso, guardando, porém, distância do mundo religioso.

$E U$ e $T U$ situa-se no centro como eixo principal de seu pensamento. As obras anteriores, sobre a mística medieval, a mística hassídica e sobre o judaísmo formam o solo inspirador de suas densas intuições sobre a experiência inefável do encontro dialógico dos homens na presença do Tu eterno. Estamos na presença de uma verdadeira fenomenologia da experiência religiosa.

Essa é a contribuição valiosa que devemos reconhecer na obra de Martin Buber. 


\section{REFERÊNCIAS}

BÍBLIA, Português. A Bíblia Sagrada: Antigo e Novo Testamento. Tradução de João Ferreira de Almeida. Edição rev. e atualizada no Brasil. Brasília: Sociedade Bíblia do Brasil, 1969.

BUBER, Martin. Ich und Du. 8. ed. Heidelberg: Lambert Schneider,1974.

BUBER, Martin. EU e TU. Tradução Newton Aquiles von Zuben. 10. ed., 4. reimpressão. São Paulo: Centauro, 2006.

BUBER, Martin. Eclipse de Deus. Campinas: Verus, 2007.

BUBER, Martin. Daniel: Die Gespräche von der Verwirklichung. Leipsig: Insel, 1913.

FISON, J.E. The blessing of the Holy Spirit. London: Longmans, 1950.

FRIEDMAN, Maurice. The life of dialogue. London: Routledge, 1955.

HAYOUN, Maurice. Martin Buber: une introduction. Paris:Pocket, 2013.

HORWITZ, Rivka. Buber's way to "I and Thou": an historical analysis and the first publication of Martin's Buber lectures “Religion als Gegenwart”. Heidelberg: Lambert Schneider, 1978.

MISRAHI, Robert. Buber: philosophe de la relation. Paris: Seghers, 1968.

SCHILPP, Paul Arthur; FRIEDMAN, Maurice. The philosophy of Martin Buber. London: Cambridge University Press, 1967. 